\title{
Interest Rate, Corporate Membership and Loan Repayment by Borrowers from Micro-Financial Institutions in Nakuru County
}

\author{
Wafula Nathan Wamalwa \\ School of Business, Kenyatta University, Nairobi, Kenya
}

Email address:

Wafula_nathan@yahoo.com

\section{To cite this article:}

Wafula Nathan Wamalwa. Interest Rate, Corporate Membership and Loan Repayment by Borrowers from Micro-Financial Institutions in Nakuru County. Journal of Investment and Management. Vol. 6, No. 1, 2017, pp. 37-43. doi: 10.11648/j.jim.20170601.16

Received: September 13, 2016; Accepted: October 20, 2016; Published: February 20, 2017

\begin{abstract}
The purpose of this study was to determine the relationship between interest rate, corporate membership and loan repayment in MFIs in Nakuru County. The study was guided by two objectives; to investigate the role of interest rate in loan repayment in MFIs in Nakuru County and to analyze the role of corporate membership in loan repayment in MFIs in Nakuru County. The study adopted correlation design and was guided by multiple regression models. The study collected data through structured questionnaires that had adequate research items on every research indicator. Collected data was analyzed using STATA and results were presented using tables. The findings of the study revealed that interest rate is not a determinant of loan repayment in Micro Financial Institutions in Nakuru County and it was concluded that interest rate charged on a loan does not impact on repayment. Similarly, it was evident that corporate membership is not significant determinant of loan Repayment in micro financial institutions in Nakuru County. The study recommends that institutions should establish a close relationship between the lenders and the borrower through monitoring, business advice and regular meetings. The institution can also develop a reward system to those borrowers who repay their loans on time through discounts on subsequent loans and savings. Further studies should be conducted to examine if the following determinants are associated with loan repayment in MFIs period of membership, security given, utmost good faith, consistency of payment during previous loan and social problems.
\end{abstract}

Keywords: Interest Rate, Corporate Membership, Loan Repayment

\section{Introduction}

The potential of using institutional credit and other financial services for poverty alleviation in Kenya is quite significant. About 18 million people, or $60 \%$ of the population, are poor and mostly out of the scope of formal banking services. According to the National Micro and Small Enterprise Baseline Survey of 1999, there were close to 1.3 million MSEs employing nearly 2.3 million people or $20 \%$ of the country's total employment and contributing $18 \%$ of overall GDP and $25 \%$ of non-agricultural GDP. Despite this important contribution, only $10.4 \%$ of the MSEs receive credit and other financial services. The formal banking sector in Kenya over the years has regarded the informal sector as risky and not commercially viable (Omino, 2005).

According to the Poverty Reduction Strategy Paper (PRSP) of 1999, a large number of Kenyans derive their livelihood from the MSEs. Therefore, development of this sector represents an important means of creating employment, promoting growth, and reducing poverty in the long-term. However, in spite of the importance of this sector, experience shows that provision and delivery of credit and other financial services to the sector by formal financial institutions, such as commercial banks has been below expectation. This means that it is difficult for the poor to climb out of poverty due to lack of finance for their productive activities. Therefore, new, innovative, and pro-poor modes of financing low-income households and MSEs based on sound operating principles need to be developed (Omino, 2005).

Over the last twenty years, there has been a proliferation of NGO programs to promote microfinance development. The organizations range from small charitable units operating in a 
limited geographical area to large institutions, covering vast tracts of the country and carrying out a variety of development and welfare activities. Increasingly, organizations have emerged whose sole objective is providing financial services to micro and small enterprises for example four Welfare Organizations have recently spinned off their microfinance activities into separate entities: from CARE, WEDCO was created, the National Council of Churches of Kenya (NCCK) established Small and Micro Enterprise Program (SMEP) Plan International created BIMAs and World Vision established (KADET).

NGOs have developed microfinance assistance models that are cost-effective and lead to sustainability. Some of the most serious threats to, and weaknesses of NGO microfinance programmes are related to their method of funding. Nearly all are donor-based, supported, or sponsored. Donors often provide facilities and create a cost-base, which the NGOs cannot sustain on their own. The schemes therefore last only as long as a donor is willing and able to support them (Aleke, 2005).

Kenya's microfinance sector consists of approximately 250 MFIs, 38 of which practice only microfinance. Of those 38,36 offer credit-only services, whereas only two are deposit-taking institutions. The remaining institutions are unregulated by the Central Bank and offer microfinance services in combination with other social services.

Kenyan society remains characterized by sharp income disparities and widespread poverty a great majority (75 percent) of the labor force is employed in informal and subsistence agriculture, although the tourism and telecom sectors have been important engines of growth in recent years.

The majority of Kenya's population (87 percent) uses no formal financial services, but instead relies on cooperative lending societies and other forms of informal savings and creditThe size of the informal financial sector in Kenya suggests a significant opportunity to extend formal financial services to many of those currently excluded from the financial mainstream. At the same time, subjecting Kenya's microfinance sector to the same prudential regulations as commercial banks may limit its ability to serve low-income, marginalized segments of the market (Wood, 2011).

Kenya has a relatively well-developed microfinance sector comprising of organizations, which can be categorized into three "sub-systems "The informal system, the semi-formal system and the formal system. The informal system are economically active people who rely on a variety of traditional and informal financial system like Rotating Savings and Credit Associations (ROSCA) and Accumulating Savings and Credit Associations (ASCA), they operate outside the structure of government regulation and supervision. The semi-formal which provide financial services and receive subsidize on credit include government agencies, MFIs and NGOs. The formal systems are financial institutions that are charted by the government and are subject to banking regulations and supervisions e.g. commercial banks (Dondo, 2005).

\subsection{Mix Markets of Micro Finance Institutions in Kenya}

Eighteen institutions responded to the survey representing $79 \%$ of the market as of FYE 2011, including Equity Bank this quarter. MFIs in Kenya expecting strong growth in both borrowers and loan portfolios in the quarter ending June 30 , but expectations for the coming twelve months for loan portfolios are significantly higher. MFIs are also confident in their ability to reduce risk in their own portfolios, but the range between the reported country level average and individual level weighted average belies the increased confidence of larger institutions. Interestingly, the leading factor across institutions for both outreach and risk is reportedly the macroeconomic environment, though the different legal statuses report different factors (Republic of Kenya, 2010).

The Kenyan microfinance continues to evolve rapidly around the proliferation of mobile payments. New partnerships continue to push the market forward, the most notable being between Equity Bank and MasterCard who together plan to issue 5 million credit/debit cards in Kenya by the end of 2013. For its part, the government has instituted an excise duty on mobile transactions. The increase in services and utilization of mobile money platforms has unfortunately also led to a rise in crime against mobile money shops. Through the end of the fourth quarter, borrower levels were down while depositor levels were up. Loan and deposit portfolios continue to climb. Kenyan MFIs are projecting strong growth in borrowers relative to previous year (a reflection of previous years of low growth) and comparable growth in GLP. Risk levels are a concern for MFIs. Political and regulatory changes are weighing on the minds of MFIs in terms of impacting both outreach and risk, but they are also concerned about client-indebtedness impacting risk levels. (Republic of Kenya, 2010)

\subsection{Micro Finance Institutions in Nakuru County}

There are a number of MFLs in Nakuru County which include Micro Kenya, Faulu Kenya, Small Medium Enterprise Program SMEP, Umoja entrepreneur Ltd, Changamka Kenya, Bimas, Ebony Capital Ltd and Real People. Faulu Kenya is one of the deposit-taking microfinance company registered in Kenya under the Microfinance Act of 2006. It is a Micro-Finance Company, with a mission to listen and empower Kenyans by providing relevant financial solutions. Faulu was founded by an NGO as a pilot programme of Food for the Hungry International (FHI), offering micro-enterprise lending in Nairobi's Mathare slum. With a wide range of services and products (including farming loans), Faulu is proving to be one of the most innovative and fast-growing micro finance institutions in Kenya. Today, Faulu serves over 230,000 clients, with over 90 outlets throughout the country. Over the years Faulu has been able to help over 500,000 Kenyans with financial solutions transforming some from poverty into capable business people (Republic of Kenya, 2012).

Small Medium Enterprise Program (SMEP) began 
operations as a small project of the National Council of Churches of Kenya (NCCK) in 1975. The Project started as a relief arm of NCCK providing the poor in the slum areas in Nairobi with food and later small business grants. It was later recognized that the project could not continue the feeding programme indefinitely and therefore ways and means had to be sought out to make people participate in meeting their daily needs and avoid dependency. It is in this spirit that a credit scheme was born. In 1990, the scheme adopted the group lending methodology (adapted from the Grameen Bank model) through support from USAID (Ministry of Trade, Kenya, 2012).

Later on NCCK made a decision to allow the programme run autonomously in order to address the problems of poverty and unemployment more effectively. SMEP was registered as a company limited by guarantee in April 1999. In 2009 SMEP became the first MFI in Kenya to partner with Safaricom M-PESA. This was to enable the organization to offer faster, safe and convenient services. In 2010 SMEP Deposit Taking Micro Finance was licensed by Central Bank of Kenya as a nation-wide Deposit Taking Micro finance. In 2012 SMEP Deposit Taking Micro finance (DTM) has released the greatest innovation in Africa by being the first MFI to provide a VISA enabled debit card to its clients (Ministry of Trade, Kenya, 2012).

\subsection{Study Objectives}

i. Determine the relationship between interest rate and loan repayment in MFIs in Nakuru County.

ii. To establish the relationship between corporate membership and loan repayment in MFIs in Nakuru County.

\subsection{Research Hypotheses}

$\mathrm{HO}_{1}$ : Interest Rate does not have significant relationship with loan repayment in micro financial institutions.

$\mathrm{HO}_{2}$ : Corporate membership does not have significant relationship with loan repayment in micro financial institutions

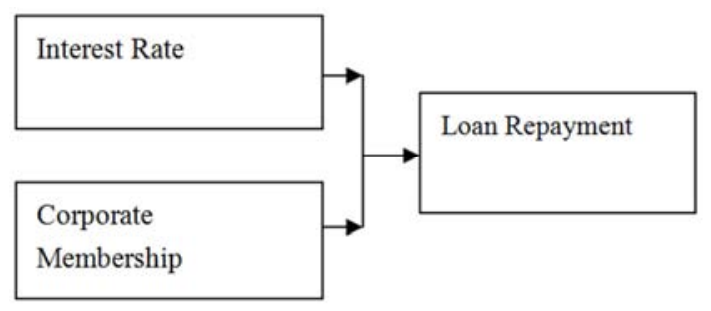

Figure 1. Conceptual Framework.

\section{Literature Review}

\subsection{Contract Theory}

Under joint liability, members of a peer lending group must have some way to ensure that the other members of the group repay their portions of the loan so that all have future access to loans. Each group devises implicit and explicit rules and norms that can diminish the risk of default, provided that repaying the loan is a utility maximizing outcome for group members. Risk management includes identifying and evaluating exposure to loss as well as selecting optimum methods of reducing exposure to risk (Mehr, 2004). A formal or informal contract between group members is a risk management method.

One way in which the seriousness of the members is proven is by attending regular meetings (Adams, 2008). An implicit opportunity cost exists by attending the meetings, as well as fines for tardiness or absenteeism in many cases. Not only does attendance at these meetings show a seriousness of intent, but it provides a forum in which mutual trust is built, ideas are shared, and strategies are discussed concerning loan repayment.

In standard neoclassical of economic theory, an optimal contract is a principal-agent problem that is comprehensive in that it specifies each party's obligations under each state of nature (Hart, 2005). The complete state-contingent contracts do not involve since each state of nature could be thought of in the beginning time period. However, in practice, it is unrealistic to define each state of nature and contracts are renegotiated frequently.

There are several reasons why complete state-contingent contracts are not feasible due to high transactions costs. First, it is difficult for people to imagine all contingencies. In addition, it is costly to negotiate each state of nature so that each member of the group has a mutual understanding of the contract under each state. Finally, it is hard to write a legally binding contract for each state of nature. Each of these costs make a comprehensive state-contingent contract primitively expensive (Hart, 2005).

In developing countries with an infinite number of potential reasons for default, an incomplete complete contract is a more realistic tool for risk management. Incomplete contracts differ from neoclassical complete contracts in that unanticipated disturbances may arise which result in renegotiation. Thus, the incomplete contract is an elastic, flexible tool. Also, incomplete contracts allow a "tolerance zone" that allows for a looser interpretation of the states of nature. This flexible type of contract can be thought of as a "framework which affords a rough indication around which such relations vary, an occasional guide in cases of doubt, and a norm of ultimate appeal when the relations cease in fact to work" (Llewellyn, 2009).

In solidarity groups, typically members have some idea ex-ante about what would happen if a member defaulted for a certain reason (state of nature). For example, if a member were sick on repayment day, certain groups might require that a family member pay for her while other groups may contribute her part until she is able to repay. Usually in the case of severe illness, the group refrains from intense peer pressure, instead showing more compassion towards the woman. The exact reaction of the group will vary from group to group and from context to context. Nevertheless, an incomplete contract may exist detailing the general consequences for a defaulting 
member under various scenarios. Rarely would this contract be written, however often times, an oral agreement has been reached as to the group reaction under various states of nature. In other cases, the contract may be an implicit social contract (Fafchamps, 2002) where no promises have been made either in writing or orally, yet group members understand the probable consequences of defaulting in different states of nature. Ex ante, an explicit or implicit incomplete contract exists in solidarity groups that define the general reaction of the group to a defaulting member.

This intragroup contract defines how the group will react, either by punishing or assisting the defaulting member given different reasons for default. The ex-ante intragroup contract provides a framework which may curtail shirking and encourage correct repayment. Since the ex-ante intragroup contract is incomplete, the contract may be modified ex post as unforeseen states of nature are revealed. This theory is relevant to this study in that the loan repayment by the borrower is dependent on various states of nature such as the interest rate, Age of borrowers, level of education, level of income, and corporate membership which needs to be addressed (Hart, 2005).

This study relies on step wise elimination theory because given various $\mathrm{x}$ vectors under study it tries to eliminate those that are statistically insignificant between the statistically significant for the study.

\subsection{Interest Rate}

Interest rate is flexible amongst institutions depending on the type of loan one is taking. Many authors have observed that interest rate affects loan repayment (Oke and Adeyemo, 2007). Interest rate is (the compensation for the service and risk of lending money) which is a major factor of income institutions can earn by lending money, of bond pricing and of the amount they will have to pay to borrow money, it is important that you understand how prevailing interest rates change: primarily by the forces of supply and demand, which are also affected by inflation and monetary policy. Of course, when you are deciding whether to invest in a debt security, it is important to understand how its characteristics determine what kind of interest rate you can receive so as to avoid hardship in paying back the loan (Heakal, 2013).

\subsection{Corporate Membership}

Some scholars say that corporate membership affects loan repayment while others dispute this facts stating that when a persons is a member to other financial institution especially the informal sector that do not have strict rule and regulation, that money borrowed from the group in just paid back due to the trust that bind them together as members for common objective, this kind of person is better place to repay the loan in the formal institution unlike those who are not corporate members (Oke and Adeyemo, 2007).

\subsection{Empirical Literature}

According to study by Oke and Adeyemo (2007) whose purpose was to analyze microcredit repayment in southern Nigeria. They used a multi stage stratified random sampling procedure to collect data from members of microfinance institution (MFI) in the study. Linear multiple regression was used to determine the variables that affected the microcredit repayment. The variables that significantly influence repayment are income, distance between dwelling places and the bank, amount of business investment, social culture experiences, amount of loan borrowed, access to business information, penalty for lateness to group meetings, membership to corporate societies, number of days between loan application and disbursement and poverty were analyzed. Poverty was found to hamper repayment; never the less the study supports findings that most members of microcredit are credit worthy.

Okurut and Kinyondo (2009) conducted a study investigating factors that influence loan repayment among group clients of Microcredit institutions in Tanzania. Logit model regression was used and the results suggested that experience, training time and sanctions have positive and significant effects on loan repayment performance. However transaction costs and group size have negative and significant effects on loan repayment performance.

Chaudhary \& Ishafq (2003) examined the credit worthiness of 224 rural borrowers in Pakistan. Using logistic regression, they found that borrowers with higher educational levels, involved in a non-farm business activity, who were using the loans for investment and were female, had a higher probability of repaying their loan. The study found that the subsidized interest rate level did not have a significant effect on repayment behaviour among rural borrowers in Pakistan. They concluded that a subsidised interest rate was not the best way to ensure good repayment by borrowers.

The determinants of loan repayment rates for agricultural loans were investigated by (Brehanu \& Fufa, 2008). Using probit and logit regression, they conducted a study on the determinants of repayment performance among small-scale farmers in Ethiopia. In the study, they found that borrowers with larger farms, higher numbers of livestock and farms located in a rainfall area had a higher capacity to repay loans, since all those factors increased the farmers' productivity and income. The study also found that borrowers who had extra business income and were experienced in using agricultural technology had a good repayment performance.

Wongnaa, \& Awunyo (2013) conducted a study to analyze the factors that are critical in improving loan repayment by yam farmers in the Sene district of Ghana. Random sampling technique was used to select 100 respondents in the district and structured questionnaire was administered to collect data. Descriptive statistics and the probit model were employed. The results show that $42 \%$ of yam farmers in Sene district are illiterates. More males (93\%) are involved in yam farming than females (7\%) and most of the farmers are married (91\%). Also most of the yam farmers in the district have a family size of 6-10 households (66\%) and 54\% of them have 1-10 years of yam farming experience. Also, the results show that education, experience, profit, age, supervision and off-farm income have 
positive effects on loan repayment performance. Conversely, gender and marriage have negative effects on loan repayment while the effect of household size was found to be ambiguous.

According to Roslan \&Karim (2009) conducted a study on microcredit loan borrowers from Agro Bank Malaysia. Agro Bank is a commercial institution specializing in loans to borrowers involved in agricultural business. Apart from giving large-scale loans, it also provides small-scale loans, such as microcredit loans, to borrowers. In their research, they found that male borrowers and borrowers who had a longer duration for repayments had a higher probability of defaulting. Borrowers involved in non-production oriented business activities such as in the service or the support sectors who had training in their particular business and who borrowed higher loans had lower probabilities of defaulting there payments in the banks Guatemalan microfinance borrowers.

Mohammad \& Hooman, (2008) undertook a study to investigate the factors influencing on loan repayment behavior of the famers that secured loans from Agriculture bank using logit model. Results showed loan interest rates is the most important factor affecting repayment of loan. Famers experience and total applications are the next factors respectively.

According to Oladeebo \& Oladeebo (2008), they examined social economics factors influencing loan repayment among small scale farmers in Ogbomoso Agriculture zone of Oye state Nigeria. They collected data using a multistage random sampling technique and analyzed using descriptive statistics and ordinary least square multiple regression analysis. The results showed that the amount of loan obtained by farmers, years of farming experience with credit use and level of education were the major factors that positively and significantly influenced loan repayment, however age of the farmers influenced negatively but significantly.

Samiya \& Abdullahi, (2008) conducted a study to analyze factors affecting loan performance of women in Harar Microfinance Institution. The study was mainly based on primary and secondary data. Descriptive statistic and Logit regression were used to compare the two groups (defaulters and non-defaulters) with respect to some explanatory variables. The findings revealed that loan repayment performance of women were affected by social economic, demographic and institutional factors.

Olade \& Oyewol, (2005) conducted a study whose aim was to determine factors influencing defaults in loan repayment among poultry farmers in Ijebu Ode local government area of Ogun state. Probit model was used to determine and analyze the factors affecting loan repayment in the study area. Descriptive study was also used to describe social economics characteristics of farmers. Findings revealed that majority of farmers in the study area are educated. Age of the farmers significantly influenced default in loan repayment, while educational level and income of the farmers also significantly influenced default in loan repayment.

According to Malarivizhi et al. (2010) who conducted a study who employed a cross sectional design with stratified sampling method to examine how common household factors affect repayment performance of Amanah Ikhtiar Malaysia (AIM) hardcore poor micro credit program clients in Peninsular Malaysia. The study designed and tested a structural equation model to investigate how uses of loan, household income, numbers of sources of income and total savings affects repayment performance. Findings of this study shows a significant model fit and negative linear relationship between repayment problem with uses of loan in income generating activities, also income, number of gainly employed members and numbers of sources of income.

\section{Research Methodology}

This was a correlational study. The study adopted a linear multiple regression model that was used to a certain the size of the coefficient and how the explanatory variable were significant and insignificant for the study. The target population of the study consisted 480 borrowers and 110 employees of MFIs in Nakuru. The study used stratified random sampling method to sample the respondents who were used in the study. $10 \%$ of the target population was used as a sample. This gave a total of 59 respondents to be involved as a sample in the study. The researcher edited, coded, classified and sorted the data upon collection. STATA was used to regress the data to achieve the objective of the study. The results were presented using tables.

\section{Discussion of Findings}

Regression analysis was conducted to achieve the objectives of the study;

Table 1. Regression Results.

\begin{tabular}{lllllll}
\hline Robust & & & & & \\
\hline Loan Repayment & Coef. & Std. Err. & t & P>|t| & [95\% Conf. Interval] \\
\hline Interest rate & -.1025232 & .1873571 & -0.55 & 0.587 & -.4786583 \\
Corp. Membership & .007581 & .0134744 & 0.56 & 0.576 & -.0194699 \\
Cons & 1.630979 & .2111623 & 7.72 & 0.000 & .034632 & 1.207053 \\
\hline
\end{tabular}

On interest rate, a unit increase in the interest rate, is associated with 0.1025 decreases in the repayment rate of the loan. However this relationship is not statistically different from zero. So interest rate has no impact (does not explain variations) in loan repayment. The sample interest rate is not statistically significant for the study since the $p$-value $>0.05$ as shown in table 1 above. If we control for education level, income of business, age and corporate membership, the rate of interest is not a determinant of the loan repayment rate in this sample. So the interest rate charged on a loan does not impact 
on repayment. This results are inconsistent with those of (Mohammad \& Hooman, 2008) but consistent with those of Chaudhary \& Ishafq (2003) in the empirical literature.

On corporate membership, belonging to a corporate membership is associated with 0.00751 increases in loan repayment; however this relationship is not statistically different from zero, so belonging to a corporate membership has no effect on loan repayment. Corporate membership is also not statistically significant for the study since the p-value $>$ 0.05 as shown in table 1 above hence not a determinant of loan repayment. These results are inconsistent with those of (Oke \& Adeyemo, 2007). Holding all other factors constant, belonging to a corporate membership does not help with loan repayment in this sample hence it is not a determinant of loan repayment. This could imply that the corporate memberships do not have loan repayment as one of their social objectives for the members or it could mean that because many of the borrower were members of the informal sector i.e. merry go round that is govern by trust and responsibility thus the same spirit prevail in them hence loan repayment.

The study concluded that interest rate and corporate membership are not determinants of loan repayment. The study recommends that institutions should establish a close relationship between the lenders and the borrower through monitoring, business advice and regular meetings. The institution can also develop a reward system to those borrowers who repay their loans on time through discounts on subsequent loans and savings. Further studies should be conducted to examine if the following determinants are associated with loan repayment in MFIs period of membership, security given, utmost good faith, consistency of payment during previous loan and social problems.

\section{References}

[1] Armendariz, G.. \& Murdoch, G.. (2007). The Economics of Microfinance MIT Press Cambridge, MA, U.S.A.

[2] Wongnaa C. A. \& Awunyo V. (2013). Factors Affecting Loan Repayment Performance among Yam Farmers in the Sene District, Ghana Vol V No2 2013Agris on-line Papers in Economics and Informatics.

[3] Chaudhary, M. A., \& Ishfaq, M. (2003). Credit worthiness of rural borrowers of Pakistan. The Journal of Socio-Economics, $32,675-684$.

[4] CBS-GoK, (2007). Economic survey, Ministry for Planning and National Development, Nairobi.

[5] Abdullah A. Mamun, C. A. \& Mariapun S. (2010). Examining Critical Factors Affecting the Repayment of Microcredit of Malaysia.

[6] Abdullahi S. (2008). Factors Affecting Loan Repayment Perfomance of Women in Ethiopia. Analysis of the case of Harari Microfinance Institutions.

[7] Adeyemo R, Agbonlahor, M. U. \& Oke, J. T. O. (2007), an empirical Analysis of Micro credit repayment in South Western Nigeria. Human and social sciences journal 2(1): 63-73; 2007.
[8] Hooman M. \& Mohammed R. (2008), Factors influencing on repayment behavior of Khorazan Province.

[9] Linsky, K. (2008). The Innovative Entrepreneur, Macmillan Publishers, Nairobi.

[10] Oladebe O. L, Oni O. A and Oyewole I. K (2005). An Analysis of Factors Influencing loan Default Among Poultry Farmers in Nigeria.

[11] Oladeebo. J. O and Oladeebo O. E, (2008) Determinants of loan repayment among smallholder Farmers in Ogbomoso Agricultural Zone of Oyo state. Journal of Social Science 17 (1): 59-62.

[12] Paul, S. (2008). The New Born Day in Cooperative Loans, McGraw Hill, Southampton.

[13] Mugenda M. O. \& Mugenda A. G.. (2003). Research Methods: Quantitative \& Qualitative approaches, Nairobi Acts Press.

[14] Roslan, A. H., \& Abd Karim, M. Z. (2009). Determinants of microcredit repayment in Malaysia: The case of Agrobank. Humanity \& Social Sciences Journal, 4 (1), 45-52.

[15] Mudida, (2003). Modern Economic (Nairobi: Focus Publication Ltd.).

[16] Brehanu, A., \& Fufa, B. (2008). Repayment rate of loans from semi-formal financial institutions among small-scale farmers in Ethiopia: Two-limit Tobit analysia. The Journal of Socio-Economics, 37, 2221-2230.

[17] Smith, P., \& Thurman, E. (2007). A billion Strarp: Microcredit, Barefoot banking, and The business Solution for Ending Poverty New York: McGraw Hill

[18] Republic of Kenya, (2012) Small Medium Entrepreneur program (SMEP) journal.

[19] George O., (2005). Regulation and supervision of microfinance institutions in Kenya. Central bank of Kenya.

[20] Afolabi, F. (2010). Analysis of loan repayment among farmers in oyo state Nigeria Kampla-Raj 2010 soc sci, 22920; 115: 119, (2010).

[21] Aleke D., (2005). The status of microfinance in Kenya.

[22] Hoff, F. \& Joseph S. (2000). World Bank report No 58Fehr, E. and Fischbacher, U (2002). Why social preferences matter the impact of non-selfish motives on competition, cooperation and incentives. The Economic Journal 112 (478), pp. C1 C33.

[23] Francis N. \& Abel A. K., (2009). Determinants of loan repayment performance in microcredit institutions: evidence from Tanzania.

[24] Consultative Group to Assist the Poor C GAP G8 Microfinance policy document.

[25] Priscilla N. W., (2011). Factors that Influence the Demand for Credit for Credit Among Small-Scale Investors: a case study of Meru Central District, Kenya. Research Journal of Finance and Accounting. 2, (2).

[26] Cassian N. J. (2008). Central bank of Kenya. The status of Micro financial institutions in Kenya.

[27] Stephen S., (2011). Factor influencing repayment of loan among group borrowers case study of group business in Bungoma District. 
[28] Yunus, M. (2004). Banker to the Poor: The Autobiography of Muhammad Yunus, Founder of Grameen Bank, Oxford University Press: USA, ISBN 0-19-579537-7.

[29] Vogelgesang, A. (2003). Microfinance in Times of Crisis: The Effect of Competition, Rising Indebtedness, and Economic Crisis on Repayment Behavior" World Development. 31 (2).

[30] Daley-Harris, S. (2006). State of the Microcredit Summit. Available at www.microcreditsummit.org/pubs/reports/socr/Z2006/SOCR $\varphi$ 6.pdf.

[31] Bestwand, J. (2006). Research in education (6th edition).

[32] Singel N. (2003). Research Methods for managers. A skill-building approach $\left(2^{\text {nd }} \mathrm{ed}\right)$. New York; wily Publishers.

[33] Cooper D. R. and Schindler P. S. (2003). international Edition; Business Research Methods 8thed; New Deihi; Mac Graw-Hill.

[34] CBS-GoK (2003). Economic Survey, Report by Task Force on Micro and Small Scale Enterprises: Nairobi. Ministry of Labour and Human Resource Development, Nairobi.

[35] David Wood, (2011). Impact Investing A Framework for Policy
Design and Analysis Microfinance Act Case Study 11: Republic of Kenya, (2010). Microfinance in Kenya Country Briefing, Washington, DC: www.mixmarket.org/mfi/country/Kenya/report.

[36] Peng C. J. and Lee, G. M. Ingersoll (2002). An Introduction to Regression Analysis and Reporting; The Journal of Educational Research, 96 (1).

[37] Godquin, M. (2004). "Microfinance Repayment Performance in Bangladesh: How to Improve the Allocation of Loans by MFIs”, World Development, Vol. 32, (11), 1909-1926.

[38] Akerlof, G. A. (2010). "Procrastination and Obedience," Working Papers Series No.13, Institute for Policy Reform, Washington, D. C.,

[39] Adams, D. And Canavosi, M. L (2008). "Rotating Savings and Credit Associations in Bolivia" Informal Finance in Low-Income Countries ed. Adams, D. W. and Fitchett, D. A., Westview Press, Boulder, CO.

[40] Hart, O., and Holmström, B. (2005) "The Theory of Contracts" Advances in Economic Theory ed. T. Besley, Cambridge University Press, Cambridge.

[41] Republic of Kenya, (2013). Associations of Micro Financial institution in Kenya (AMFI-K) Report. 